\title{
KARAKTERISTIK PERINDUSTRIAN GENTENG DI DESA SIDOLUHUR KECAMATAN GODEAN KABUPATEN SLEMAN
}

\author{
Oleh : \\ Sriadi Setywati, Hastuti, dan Nurhadi \\ Jurusan Pendidikan Geografi, Fakultas Ilmu Sosial, Universitas Negeri Yogyakarta \\ Sriadigeo@yahoo.com
}

\begin{abstract}
Abstrak
Tujuan penelitian ini adalah untuk mengetahui: (1) faktor - faktor yang menyebabkan pengusaha industri genteng tidak berproduksi lagi,(2) faktor yang mendorong dan menarik pada usaha industri genteng,(3). persebaran pengusaha industri genteng. 4). Pemasaran dan peta pemasaran genteng di Desa Sidoluhur Kecamatan Godean Kabupaten Sleman.Populasi penelitian ini adalah mantan pengusaha industri genteng dan pengusaha industri genteng. Populasi mantan pengusaha industri genteng berjumlah 14 kepala rumah tangga, karena jumlahnya kurang dari 100, maka semua digunakan sebagai responden. Populasi pengusaha industri genteng berjumlah 388 kepala rumah tangga, tersebar pada delapan dusun. Penelitian ini mengambil sampel 126 kepala rumah tangga pengusaha. Dengan area sampling diambil tiga dusun sampel daerah penelitian, yaitu Dusun Berjo Kulon 48 kepala rumah tangga, Berjo Kidul 33 kepala rumah tangga dan Serangan 45 kepala rumah tangga. Setelah data terkumpul kemudian dianalisis, menggunakan analisis deskriptif dengan tabel persentase.Hasil penelitian menunjukkan: 1). Faktor yang menyebabkan pengusaha industri genteng tidak berproduksi lagi, paling banyak disebabkan oleh keterbatasan modal berjumlah 6 pengusaha atau $42,85 \%$. Paling sedikit disebabkan oleh sulit memperoleh tenaga kerja, usia dan tidak ada generasi penerus serta kurang ketrampilan berinovasi, masing-masing berjumlah 1 pengusaha atau 7,15 \%. 2). Faktor pendorong industri genteng adalah merupakan mata pencaharian utama dengan jumlah paling banyak, yaitu 108 pengusaha atau $85,71 \%$. Faktor pendorong yang paling sedikit yaitu usaha dirintis sendiri berjumlah 5 pengusaha atau 3,97 \%. Faktor penarik yang paling banyak keuntungan cukup untuk memenuhi kebutuhan berjumlah 66 pengusaha atau 52,38 \% dan faktor penarik yang paling kecil yaitu membuka lapangan pekerjaan bagi lingkungan sekitar, berjumlah 4 pengusaha atau 3,97 \%. 3). Persebaran pengusaha industri genteng menunjukkan pola memanjang " linear " searah dengan jalan dan terdapat perbedaan aglomerasi industri genteng di tiga daerah sampel penelitian. 4). Pemasaran genteng ke luar kota, semua pengusaha yaitu 126 pengusaha atau 100 persen memasarkan ke Kota Yogyakarta. Pemasaran luar kota yang paling kecil ke Kota Semarang berjumlah 2 pengusaha atau 1,59 persen.
\end{abstract}

\section{Kata kunci : Industri genteng, tidak berproduksi}

\section{Pendahuluan}

Pembangunan industri kecil sangat bermanfaat bagi penduduk dan pemerintah. Manfaat bagi penduduk sebagai peluang pekerjaan dan menambah pendapatan. Bagi pemerintah dapat membantu mengatasi kemiskinan dan meningkatkan kesejahteraan 
penduduk, sehingga keadaan ekonomi penduduk dapat meningkat. Keberhasilan pembangunan ekonomi suatu negara dapat dilihat dari majunya sektor industri di desa, yang dapat meningkatkan taraf hidup masyarakat disekitarnya.

Industri pedesaan adalah suatu bentuk transisi antara industri yang bersifat tradisional dengan industri modern. Industri pedesaan dapat berfungsi sebagai alat pertumbuhan ekonomi. Industri pedesaan melalui mekanisme pasar dapat mengakumulasi dan mengalihkan modal dari sektor pertanian ke sektor industri. Industrialisasi pedesaan dapat pula meningkatkan penyerapan tenaga kerja yang senantiasa bertambah di pedesaan. Industrialisasi pedesaan juga berfungsi meningkatkan kesejahteraan sosial ekonomi. Industrialisasi pedesaan bertujuan untuk menganekaragamkan ekonomi pedesaan, melalui penciptaan lapangan kerja baru, peningkatan pendapatan dan peningkatan produktivitas ekonomi masyarakat pedesaan ( Marzuki Usman, 1990 : ii ).

Industri genteng di Desa Sidoluhur merupakan salah satu industri yang telah dikembangkan dan menjadi tulang punggung perekonomian di Desa Sidoluhur Kecamatan Godean Kabupaten Sleman. Agar industri genteng dapat dipertahankan maka, sektor industri ini harus dapat berkembang secara bertahap. Adanya industri genteng di Desa Sidoluhur juga tidak terlepas dari beberapa faktor yang mendorong (faktor dari dalam indutri) dan faktor yang menarik (faktor dari luar industri). Proses industri genteng membutuhkan tenaga kerja yang banyak, sehingga kegiatan ini dapat menyerap tenaga kerja dan meningkatkan kesejahteraan penduduk. Perkembangan industri genteng tidak seperti apa yang diharapkan, mengalami berbagai hambatan yang berhubungan dengan proses produksi. Adanya keterbatasan modal membuat industri ini kurang berkembang. Hambatan lainnya seperti kualitas bahan baku, yang sangat berhubungan dengan kualitas genteng. Keadaan cuaca dan berkurangnya bahan - bahan untuk pembuatan genteng akan memperlambat proses produksi. Selain faktor-- faktor tersebut industri ini juga mengalami hambatan dalam hal pemasaran dan persaingan antara pengusaha. Harga genteng juga bervariasi antara pengusaha satu dengan pengusaha yang lain, sehingga terjadi persaingan harga. Industri genteng di Desa Sidoluhur sulit berkembang, karena pengusaha industri genteng jumlahnya menurun. Sehingga terdapat beberapa industri genteng yang tidak berproduksi lagi. Maka keberadaan industri genteng tidak terlepas dari adanya faktor - faktor yang menyebabkan jumlah industri genteng semakin berkurang dan beberapa industri genteng tidak berproduksi lagi, serta faktor lokasi atau letak industri. Maka distribusi atau sebaran pengusaha industri genteng penting untuk diketahui. Ternyata di Desa Sidoluhur tidak terdapat peta sebaran pengusaha industri genteng dan peta pemasaran industri genteng.Tujuan dalam penelitian ini adalah untuk mengetahui: faktor - faktor yang menyebabkan pengusaha industri genteng tidak berproduksi lagi, faktor - faktor yang mendorong dan menarik pada usaha industri genteng, peta persebaran pengusaha industri genteng, dan pemasaran dan peta pemasaran genteng

\section{Metode Penelitian}

Penelitian ini merupakan penelitian deskrptif kuantitatif. Tahap-tahap yang dilalkukan dalam penelitian ini adalah: 
Penelitian ini dilaksanakan melalui tiga tahapan, yaitu tahap persiapan, tahap kerja lapangan dan tahap kerja akhir/penulisan laporan, adalah sebagai berikut :

a. Tahap Persiapan

Pada tahap ini langkah pertama adalah menentukan daerah penelitian, diikuti dengan kegiatan studi pustaka dan mengadakan observasi. Kemudian menyusun proposal penelitian, diteruskan dengan usulan penelitian. Setelah proposal penelitian disetujui dilanjutkan dengan seminar proposal penelitian. Sehingga didapatkan masukan untuk membantu jalannya penelitian. Kemudian pembenahan seperlunya sambil menyiapkan perlengkapan penelitian. Aktivitas akhir tahap persiapan ini adalah merencanakan kegiatan di lapangan.

b. Tahap Kerja Lapangan

Setelah aktivitas pada tahap persiapan selesai diteruskan dengan tahap kerja lapangan. Yaitu ketempat lokasi daerah penelitian, untuk mencari data primer yang diperoleh melalui wawancara dengan responden. Mengumpulkan informasi dan selalu memelihara hubungan harmonis dengan responden. Sehingga pada tahap ini merupakan suatu pengumpulan data yang efektif untuk memperoleh informasi yang relevan sebanyak - banyaknya dari responden. Serta selalu berpegang pada tujuan dan permasalahan penelitian. Hasil kerja lapangan adalah terkumpulnya data hasil kerja lapangan.

c. Tahap Kerja Akhir

Pada tahap kerja akhir ini dilakukan analisis data yang merupakan satu bagian tak terpisahkan dari tahap - tahap sebelumnya. Selanjutnya membuat laporan hasil penelitian. Analisis data dilakukan dalam suatu proses, dikerjakan sesudah semua data yang diperlukan terkumpul. Kegiatan akhir pada tahap ini adalah menulis laporan dalam bentuk laporan penelitian.

Variabel penelitian pada penelitian ini adalah sebagai berikut:

a. Faktor penyebab industri genteng tidak berproduksi lagi adalah : merupakan faktor yang menyebabkan kegiatan pengusaha industri genteng tidak berproduksi lagi. Faktor - faktor tersebut adalah, sulit memperoleh tenaga kerja dan bahan baku, persaingan antar pengusaha, usia dan tidak ada generasi penerus, keterbatasan modal dan kurang ketrampilan dalam berinovasi.

b. Faktor pendorong adalah : faktor dari dalam rumah tangga, yang menyebabkan bekerja pada usaha industri genteng. Faktor tersebut adalah, industri genteng merupakan mata pencaharian utama, usaha turun temurun dan usaha dirintis sendiri.

c. Faktor penarik adalah : merupakan faktor dari usaha industri genteng, yang menyebabkan rumah tangga tersebut tertarik dan bekerja pada usaha industri genteng. Faktor tersebut adalah, keuntungan cukup untuk memenuhi kebutuhan, membuka lapangan pekerjaan bagi lingkungan sekitar, banyak pesanan, usaha dikerjakan bebas tidak terikat jam kerja.

d. Pemasaran genteng adalah : kegiatan pendistribusian genteng di dalam dan ke luar kota, karena ada penawaran dan permintaan dari penjual kepada pembeli, setelah terdapat kesepakatan harga. 
Terdapat dua jenis populasi dalam penelitian ini. Pertama adalah populasi mantan pengusaha industri genteng yang berjumlah 14 kepala rumah tangga. Karena jumlahnya sedikit maka semua digunakan sebagai responden. Persebaran kepala rumah tangga mantan pengusaha industri genteng di Desa Sidoluhur adalah sebagai berikut : Dusun Berjo Kulon sebanyak 4 pengusaha atau 28,57 persen, Dusun Berjo Kidul sebanyak 8 pengusaha atau 57,14 persen dan Dusun Serangan sebanyak 2 pengusaha atau 14,29 persen. Populasi ini digunakan untuk menjelaskan tujuan penelitian yang pertama. Kedua adalah populasi kepala rumah tangga pengusaha industri genteng, berjumlah 388 pengusaha tersebar di 8 dusun. Dengan area sampling diambil 3 dusun, dusun pertama adalah dusun yang terletak paling dekat dengan jalan raya yaitu Dusun Berjo Kulon. Dusun kedua adalah dusun yang letaknya agak jauh dari jalan raya yaitu Dusun Berjo Kidul. Dusun ketiga adalah dusun yang letaknya jauh dari jalan raya yaitu Dusun Serangan. Ketiga dusun sampel juga merupakan dusun yang jumlah pengusahanya paling banyak dibandingkan dengan dusun laninnya. Dengan metode Solvin, diperoleh jumlah sampel sebagai berikut: Dusun Berjo Kulon 48 kepala rumah tangga, Dusun Berjo Kidul 33 kepala rumah tangga, dan Dusun Serangan 45 kepala rumah tangga.

Analisis data dalam penelitian ini menggunakan analisis deskriptif, menggunakan tabel persentase. Sebelum data dianalisis diadakan editing dan koding, agar data mudah dianalisis. Selanjutnya memindahkan data ke dalam tabel kemudian dianalisis dengan membaca dan menafsirkan tabel - tabel hasil penelitian berdasarkan persentase jumlahnya.

\section{Hasil dan Pembahasan}

1. Faktor Faktor yang Menyebabkan Pengusaha Industri Genteng Tidak Berproduksi Lagi

Sebagian besar penduduk di Desa Sidoluhur mengusahakan industri genteng, karena industri ini sudah merupakan mata pencaharian utama bagi penduduk. Tetapi sekarang jumlahnya semakin berkurang. Hal ini disebabkan sulit memperoleh tenaga kerja dan bahan baku, persaingan antar pengusaha, tidak ada generasi penerus, keterbatasan modal, kurang ketrampilan berinovasi. Faktor- faktor yang menyebabkan pengusaha industri genteng tidak berproduksi lagi adalah sebagai berikut:

Tabel 1. Faktor Faktor yang Menyebabkan Pengusaha Industri Genteng Tidak Berproduksi Lagi

\begin{tabular}{|c|l|c|c|}
\hline No & \multicolumn{1}{|c|}{ Faktor Penyebab } & $\begin{array}{c}\text { Jumlah } \\
\text { (Pengusaha ) }\end{array}$ & Persentase \\
\hline 1 & Sulit memperoleh tenaga kerja & 1 & 7,15 \\
\hline 2 & Sulit memperoleh bahan baku & 3 & 21,43 \\
\hline 3 & Persaingan antar pengusaha & 2 & 14,27 \\
\hline 4 & Usia dan tidak ada generasi penerus & 1 & 7,15 \\
\hline 5 & Keterbatasan modal & 6 & 42,85 \\
\hline 6 & Kurang ketrampilan berinovasi & 1 & 7,15 \\
\hline & & 14 & 100,00 \\
\hline
\end{tabular}

Sumber : Data Primer, 2013 
Faktor yang menyebabkan pengusaha industri genteng tidak berproduksi di Desa Sidoluhur paling banyak disebabkan oleh keterbatasan modal sebesar 6 pengusaha ( 42,85 persen ). Modal merupakan faktor produksi yang penting dalam suatu usaha sehingga usaha yang dijalankan dapat terus berproduksi. Karena modal terbatas maka menyebabkan industri genteng tidak dapat berproduksi lagi. Kemudian sulit memperoleh bahan baku sebesar 3 pengusaha ( 21,43 persen ), sulit memperoleh bahan baku, disebabkan terbatasnya alat angkut truk dan bahan baku di Desa Sidoluhur yaitu di Bukit Berjo sudah tidak dapat mencukupi lagi. Hal ini berdampak menghambat para pengusaha untuk menyediakan bahan baku. Sulit memperoleh tenaga kerja sebesar 1 pengusaha ( 7,15 persen ), hal ini mengakibatkan para pengusaha berfungsi ganda, selain sebagai pengusaha mereka juga sebagai tenaga kerja, sehingga dapat menghambat dalam proses produksi. Faktor usia dan tidak ada generasi penerus serta kurang ketrampilan berinovasi, masing - masing 1 pengusaha ( 7,15 persen ). Faktor usia dikarenakan usia sudah lanjut atau tua. Sehingga tidak ada generasi penerus, karena generasi muda saat ini tidak tertarik dengan usaha industri genteng. Kurang ketrampilan berinovasi adalah pengusaha belum melakukan inovasi produk. Produk genteng yang dihasilkan kurang bervariasi, hanya satu jenis produk yaitu genteng jenis paris saja atau genteng biasa, sedangkan selera konsumen sudah berubah. Sehingga tidak dapat bersaing dan berhenti tidak berproduksi lagi.

2. Faktor Pendorong dan Penarik pada Usaha Industri Genteng

Meskipun jumlah pengusaha industri genteng berkurang, ternyata masih terdapat beberapa pengusaha industri genteng yang tetap berusaha untuk mempertahankan agar usahanya tetap dapat berjalan. Hal ini karena terdapat faktor faktor yang mendorong dan menarik pada usaha industri genteng, adalah sebagai berikut :

Tabel 2. Faktor Pendorong dan Penarik pada Usaha Industri Genteng

\begin{tabular}{|c|c|c|c|c|c|c|}
\hline No & $\begin{array}{l}\text { Faktor } \\
\text { Pendorong }\end{array}$ & $\begin{array}{c}\text { Jumlah } \\
\text { Pengusaha }\end{array}$ & $\%$ & Faktor Penarik & $\begin{array}{c}\text { Jumlah } \\
\text { Pengusaha }\end{array}$ & $\%$ \\
\hline 1 & $\begin{array}{l}\text { Mata } \\
\text { pencaharian } \\
\text { utama }\end{array}$ & 108 & 85,71 & Pemasaran lancar & 42 & 33,33 \\
\hline 2 & $\begin{array}{l}\text { Usaha turun } \\
\text { Temurun }\end{array}$ & 13 & 10,32 & $\begin{array}{l}\text { Keuntungan cukup untuk } \\
\text { memenuhi kebutuhan }\end{array}$ & 66 & 52,38 \\
\hline 3 & $\begin{array}{l}\text { Usaha dirintis } \\
\text { Sendiri }\end{array}$ & 5 & 3,97 & $\begin{array}{l}\text { Membuka lapangan } \\
\text { pekerjaan bagi lingkungan } \\
\text { sekitar }\end{array}$ & 4 & 3,17 \\
\hline 4 & - & - & - & Banyak pesanan & 9 & 7,17 \\
\hline 5 & - & - & - & $\begin{array}{l}\text { Usaha dikerjakan bebas } \\
\text { tidak terikat jam kerja }\end{array}$ & 5 & 3,97 \\
\hline & Jumlah & 126 & 100,00 & Jumlah & 126 & 100,00 \\
\hline
\end{tabular}

Sumber : Data Primer

Faktor pendorong dalam penelitian ini yaitu, usaha industri genteng merupakan mata pencaharian utama sebesar 108 pengusaha ( 85,71 persen ), karena penduduk di 
Desa Sidoluhur banyak yang mendapatkan penghasilan dari usaha industri genteng. Usaha industri genteng merupakan usaha turun temurun sebesar 13 pengusaha ( 10,32 persen ), hal ini menunjukkan bahwa pengusaha berusaha melestarikan industri genteng. Karena industri ini merupakan warisan dari orang tua, sehingga sampai sekarang usaha industri genteng masih dapat berjalan, meskipun jumlahnya cenderung berkurang. Disamping itu usaha industri genteng merupakan usaha yang dirintis sendiri sebesar 5 pengusaha ( 3,97 persen ). Pengusaha yang merintis usaha sendiri ini awalnya sebelum manjadi pengusaha mereka bekerja sebagai buruh pada industri genteng. Kemudian mereka berusaha untuk mendirikan dan menjalankan usaha sendiri. Maka mereka berusaha untuk selalu menjaga agar usahanya dapat berjalan terus.

Faktor penarik dalam penelitian ini yaitu pemasaran yang lancar sebesar 42 pengusaha ( 33,33 persen), menarik pengusaha menekuni usahanya sampai sekarang masih memproduksi genteng. Keuntungan dapat memenuhi kebutuhan sebesar 66 pengusaha ( 52,38 persen ), terutama untuk memenuhi kebutuhan primer rumah tangganya. Usaha industri genteng dapat membuka lapangan pekerjaan sebesar 4 pengusaha ( 3,17 persen ), karena proses produksi industri genteng membutuhkan tenaga kerja yang banyak, maka dapat membuka lapangan pekerjaan bagi lingkungan sekitar. Banyaknya pesanan juga merupakan faktor penarik sebesar 9 pengusaha ( 7,14 persen ), karena selain dari konsumen yang membeli secara langsung, ada beberapa juragan ( industri skala besar ) memesan genteng pada industri skala rumah tangga untuk memenuhi permintaan konsumen. Faktor penarik lainnya adalah waktu dapat dikerjakan tidak terikat jam kerja sebesar 5 pengusaha ( 3,97 persen ). Jam kerja produksi genteng dapat dilakukan malam hari, kecuali proses penjemuran genteng, karena penjemuran genteng masih menggunakan panas dari sinar mata hari. Maka penjemuran genteng dikerjakan pada siang hari.

3. Persebaran Pengusaha Industri Genteng

Persebaran pengusaha industri genteng ini merujuk pada lokasi industri, berjumlah 126 pengusaha. Adalah sebagai berikut :

Tabel 3. Persebaran Industri Genteng

\begin{tabular}{|c|l|c|c|}
\hline No & Dusun & Jumlah industri & Persentase \\
\hline 1 & Berjo Kulon ( dekat ) & 48 & 38,10 \\
\hline 2 & Berjo Kidul (agak jauh ) & 33 & 26,19 \\
\hline 3 & Serangan ( jauh ) & 45 & 35,71 \\
\hline & Jumlah : & 126 & 100,00 \\
\hline
\end{tabular}

Sumber : Data Primer 2013

Penelitian ini mengambil tiga dusun sebagai daerah penelitian, dengan aksessibilitas yang berbeda-beda. Pertama Dusun Berjo Kulon dengan jumlah 48 atau 38,10 persen, lokasi dusun ini dekat dengan jalan raya, merupakan sentra industri genteng Desa Sidoluhur. Kedua dusun Berjo Kidul dengan jumlah 33 industri atau 26,19 persen, lokasi dusun ini berada agak jauh dari jalan raya. Ketiga Dusun Serangan 
dengan jumlah 45 industri atau 35,71 persen, lokasi dusun ini berada jauh dari jalan raya. Peta persebaran pengusaaha industri genteng adalah sebagai berikut :

Dari peta tersebut dapat disimpulkan bahwa sebaran industri genteng di Desa Sidoluhur menggambarkan pola memanjang atau "linear" searah dengan jalan di semua dusun penelitian. Berarti adanya jalur transportasi berhubungan dengan mudah tidaknya lokasi industri genteng tersebut dijangkau, guna mendistribusikan hasil industri genteng. Karena lokasi dusun sampel penelitian berbeda aksessibilitasnya, maka terdapat perbedaan aglomerasi atau pengelompokan skala industri genteng, yaitu sebagai berikut : 1). Di Dusun Berjo Kulon dekat jalan raya, terdapat aglomerasi pengusaha industri genteng skala besar. 2). Di Dusun Berjo Kidul agak jauh dari jalan raya, terdapat aglomerasi pengusaha industri genteng skala menengah dan skala rumah tangga. 3). Di Dusun Serangan jauh dari jalan raya, terdapat aglomerasi pengusaha industri skala rumah tangga.

4. Daerah Pemasaran Genteng

Pemasaran pada industri genteng pada pembahasan ini adalah pemasaran ke daerah tujuan, yaitu pemasaran ke luar kota adalah sebagai berikut:

Tabel 4. Daerah Tujuan Pemasaran Genteng ke Luar Kota

\begin{tabular}{|ll|c|c|}
\hline \multicolumn{1}{|c|}{ Daerah Pemasaran } & Jumlah Pengusaha & Persentase \\
\hline 1. & Yogyakarta & 126 & 100,00 \\
\hline 2. & Klaten & 33 & 26,19 \\
\hline 3. & Solo & 49 & 38,89 \\
\hline 4. Magelang & 66 & 52,38 \\
\hline 5. & Temanggung & 18 & 14,29 \\
\hline 6. Salatigo & 42 & 3,17 \\
\hline 7. & Semarang & 2 & 1,59 \\
\hline 8. & Purworejo & 20 & 15,87 \\
\hline
\end{tabular}

Sumber : Data Primer, 2013

Pemasaran ke luar kota yang paling kecil adalah ke Kota Semarang sebesar 2 pengusaha atau 1,59 persen. Pemasaran yang paling banyak ke kota Yogyakarta, karena semua pengusaha mengirim ke kota tersebut, sebesar 126 pengusaha atau 100,00 persen. Kemudian diikuti kota Magelang dan Solo, masing - masing sebesar 66 pengusaha atau 52,38 persen dan sebesar 49 pengusaha atau 38,89 persen. Hal ini disebabkan faktor jarak antara daerah tersebut. Gejala ini menunjukkan adanya interaksi yang besar diantara dua daerah yang jaraknya semakin dekat yaitu Kota Yogyakarta dengan Desa Sidoluhur Kecamatan Godean Kabupaten Sleman. Dan interaksi yang semakin kecil antara dua daerah, karena jaraknya semakin jauh. Peta pemasaran genteng dari Desa Sidoluhur adalah sebagai berikut :

\section{Simpulan}

1. Faktor penyebab pengusaha industri genteng tidak berproduksi lagi, karena adanya kesulitan memperoleh bahan baku dan tenaga kerja, keterbatasan alat angkut, usia dan tidak ada generasi penerus.

2. Faktor pendorong pada industri genteng yaitu, industri genteng merupakan mata pencaharian utama, usaha turun temurun dan usaha dirintis sendiri. 
3. Faktor penarik pada industri genteng adalah, adanya pemasaran yang lancar, keuntungan cukup untuk memenuhi kebutuhan, membuka lapangan pekerjaan bagi lingkungan sekitar, banyak pesanan, usaha dikerjakan secara bebas tidak terikat waktu.

4. Pemasaran genteng ke luar kota paling banyak ke Kota yogyakarta dan yang terkecil ke Kota Semarang.

5. Peta sebaran pengusaha industri genteng menggambarkan pola persebaran industri genteng adalah memanjang atau linear searah dengan jalan.

6. Terdapat perbedaan aglomerasi atau pengelompokan industri genteng, karena adanya perbedaan aksessibilitas.

\section{Saran}

1. Industri genteng di Desa Sidoluhur, dapat memberikan kesempatan kerja bagi penduduk, maka keberadaan industri ini harus tetap dijaga. Pemerintah diharapkan dapat membantu mengatasi segala kesulitan yang ada sehingga industri ini tetap berproduksi terus.

2. Dengan adanya faktor pendorong dan penarik pada industri genteng, maka industri genteng tersebut perlu dikembangkan dan dijaga kelestariannya.

3. Pemerintah diharapkan dapat membentu pengembangan jaringan pemasaran, sehingga dapat membantu memperlancar kegiatan ekonomi penduduk.

\section{Daftar Pustaka}

Ida Bagus Mantra. 2004. Demografi Umum. Yogyakarta : Pustaka Pelajar Marzuki Usman. 1990. Industri Pedesaan. Bogor : Pusat Studi Pembangunan Sugiyono. 2012. Metode Penelitian Kombinasi ( Mixed Methods). Bandung : Alfabeta. 